Марија Коцић

Универзитет у Београду

Филозофски факултет

Научни сарадник

marijakocich@gmail.com
Оригиналан научни рад

примљено: 28. мај 2014

прихваћено: 1. октобар 2014

\title{
ПРИЛИКЕ У ВЕНЕЦИЈИ ПРЕД ДРУГИ МОРЕЈСКИ РАТ: СВЕДОЧЕЊЕ ЕНГЛЕСКИХ ИЗВОРА *
}

Сажетак: У раду се говори о друштвеним и политичким приликама у Венецији током 1713. и 1714. Овај период уједно представља доба када је привођен крају Рат за шпанско наслеђе (1701-1713), након којег убрзо долази до новог сукоба Венеције и Турске, познатог као Други морејски рат (1714-1718). Грађа коришћена у истраживању потиче из Националног архива у Лондону (The National Archives at Kew Gardens, London). Обухвата извештаје енглеског представника у Венецији, Кристијана Кола, који се током боравка у овој држави упознао са приликама у овом друштву и политичкој јавности. Поред ње коришћени су и штампа, мемоарска и историографска дела, која припадају истој епохи.

Кључне речи: Венеција, Кристијан Кол, криминал, куга, мир у Утрехту, лутрија.

Преговори у Утрехту, од свог покретања, били су предмет пажње јавности у Венецији. Она и остале италијанске државе постале су заокупљене проналажењем „равнотеже“, поремећене чињеницом да су Луј XIV (1643-1715) и његов унук Филип V (1701-1746) пристали да Миланско војводство и Напуљска краљевина припадну Карлу VI (1711-1740), што је најавило јачање позиција Хабзбурговаца на Апенинском полуострву. У јавности се спекулисало са више предлога, од којих је енглеска штампа објавила онај о ограничењу расположивог броја војника на „новим“ хабзбуршким поседима у Италији. Венеција је решила да задржи под оружјем део војске за случај да Карло VI реши да провали у Италију. ${ }^{1}$ Кристијан Кол $^{2}$ наводи да је Сенат био решен да се овој опасности одупре властитим снагама. ${ }^{3}$

\footnotetext{
* Текст је настао као фазни резултат рада на пројекту Модернизащија западног Балкана (број 177009) Министарства просвете, науке и технолошког развоја Републике Србије.

${ }^{1}$ The Present State of Europe: or the Historical and Political Monthly Mercury, Giving an Account of all the Publick and Private Occurrences, Civil, Ecclesiastical, and Military, that are most Considerable in every Court, vol. XXIV. For the Month od february, London 1713 (даље: Monthly Mercury, vol. XXIV... For the Month of February), 57. Ове мере нашле су значајно место и у делу познатог „историчара“ ове епохе Пијетра Гарцонија, који је сматрао да их треба у опису дешавања из 1713. навести. Pietro Garzoni, Istoria della Repubblica di Venezia. Ove insieme narrasi la Guerra per la Successione dalle Spagne al Re Carlo II, Venezia 1719, 790-791.

${ }^{2}$ Кристијан Кол (Christian Cole, 1673-1734), служио је као секретар ерла Манчестера, током његовог
} 
У ту сврху одлучио је да један део пошаље на границу према Аустрији. ${ }^{4}$

Хладноћа није спречила да чувени карневал буде отворен крајем децембра ${ }^{5}$ и траје два наредна месеца. Његов почетак представљао је повод да се у Венецију сјати велик број људи, што је најавило и негативну страну ове светковине - пораст криминала и свакојаких људских порока. Извештаји Кристијана Кола откривају да је градом овладало разбојништво. ${ }^{6}$ Његова жртва постао је кавалијер Доти, описан као „врло добар поета и сатиричар“, стар 64 године, који је у Венецији боравио у својству нунција Бреше. Доти је прободен великим ножем док је шетао под маском улицама Венеције. ${ }^{7}$ Ускоро је уследило ново убиство. Вече након што је Доти страдао, на исти начин, убијен је младић из Кремоне. Ђовани Вентури, млетачки племић, на Великом балу ${ }^{8}$ убио је младића из Кремоне. Како је Кол навео, младић се загледао у неку жену под маском, за коју је мислио да је познаје. Након што јој је пришао, Ђовани Вентури га је усмртио бодежом, наочиглед стотину посматрача, који нису ништа предузели. ${ }^{9}$

Док су се пруске трупе спремале за прелазак реке По, напредујући према Тиролу, у Венецији су се настављала убиства, што је скретало пажњу јавности од горућих политичких проблема. У чувеном средишту стакларске индустрије, острву Мурану, ${ }^{10}$ избио је пожар. ${ }^{11}$ Почетком марта пруске трупе налазиле су се у Верони (млетачка територија) спремне да наставе према Тиролу, ${ }^{12}$ док се у Сенату гласало о опозиву амбасадора у Бечу, Виктора Зана, на чије је место изабрао Пјетра Гриманија. $^{13}$

првог мандата амбасадора у Венецији. Потом је једно време провео у Хагу и Рајсвику (1697-1699). Када је ерл Манчестер по други пут именован за амбасадора у Венецији 1707, са собом је повео и Кола у својству секретара. Краће време током 1715. Кол је добио положај резидента до доласка Алекзандера Кунингама (Alexander Cunningham), који је изабран за новог представника Енглеске у Венецији.

${ }^{3}$ The National Archives at Kew Gardens, London (даље: NAL), State Papers (даље: SP), 99 [Venice]/60, fo 8v; Венеција, 13. I 1713.

${ }^{4} \mathrm{NAL}, \mathrm{SP}, 99 / 60$, fo 10v; Венеција, 13. I 1713; друго писмо са истим датумом.

${ }^{5}$ James H. Johnson, Venice Incognito: Masks in the Serene Republic, Berkeley - Los Angeles 2011, 14. Сенат је сваке године одређивао почетак карневала, због чега је он из године у годину варирао. Поводом тога тачно су били одређени дани када је било дозвољено ношење маски. Исто, 14.

${ }^{6}$ Ово није био случај само са градом Венецијом, већ и са другим деловима њене Тераферме, попут Виченце. О томе вид. више докумената објављених у: Fausto Sartori (ed.), Sebastiano Foscari Capitano di Vicenza Dispacci 1709-1714, Venezia 2008.

${ }^{7} \mathrm{NAL}, \mathrm{SP}, 99 / 60, \mathrm{f}^{\circ} 28 \mathrm{v}$; Венеција, 3. II 1713.

${ }^{8}$ Иако је писмо на енглеском језику, Кол употребљава израз Grand Ridotto.

${ }^{9} \mathrm{NAL}, \mathrm{SP}, 99 / 60, \mathrm{f}^{\circ} 28 \mathrm{v}$.

${ }^{10}$ И поред чињенице да је представљао острво, Мурано је био интегрисан у градску територију. По Марину Сануду (1466-1536) припадао је сестијеру Санта Кроче. David Chambers - Brian Pullan (ed.), Venice. A Documentary History 1450-1630, Toronto 2001, 10. Да је у ово време утврђена територијална подела града опстала и током наредног периода потврђује настављач Франческа Сансовина, дон Ђустинијани Мартиниони, према коме је Мурано чинио саставни део четврти Санта Кроче, везујући га за парохију Санта Хелена, вулгарно Санта Лена; Francesco Sansovino, Venetia. Città Nobilissima, et singolare. Descrittqa in XIIII Libri. Con aggiunta di tutte le Cose Notabili della stessa Città, fatte \& occorse dall' Anno 1580. sino al presente 1663. da don G. Martinioni, Venetia 1663, 210.

${ }^{11}$ NAL, SP, 99/60, fo 50r; Венеција, 3. III 1713.

${ }^{12}$ NAL, SP, 99/60, fo 52r; Венеција, 3. III 1713; друго писмо са истим датумом.

${ }^{13}$ NAL, SP, 99/60, f $55 \mathrm{v}$; Венеција, 10. III 1713. 
Мир у Утрехту (11. април 1713), којим је окончан Рат за шпанско наслеђе, ${ }^{14}$ најавио је корените промене односа на Апенинском полуострву. На опасност коју је он донео Венецији надовезала се и могућност да се Порта реши да поврати Мореју, чије би освајање, по Кристијану Колу, било прилично лако извршено. ${ }^{15}$ Бродови доспели из Измира донели су вест да је Порта наставила са окупљањем војске. ${ }^{16}$ Као одговор, издата је наредба Арсеналу да сагради нове и поправи старе бродове, како би били спремни ако затреба. ${ }^{17}$ Послати су порески органи у попис ренте, коју је плаћало свако домаћинство, и бројности њихових чланова, са намером да се распишу нови порези. ${ }^{18}$

Проблем је представљала и куга, за коју је Сенат страховао да је не пренесу немачки војници. Под претњом смртне казне, била је забрањена трговина са немачким територијама. Док су доношене ове прохибитивне мере, Сенат није престајао да се нада да ће Карло VI одустати од слања војске у Италију, ${ }^{19}$ што је оцењено као „врло сурова одлука““, имати. Средином априла стигло је писмо Карла Руцинија, представника Венеције у Утрехту, са вестима о миру, који је потписан у том граду. ${ }^{21}$ Прве импресије поводом тога Кол наводи у писму од 28. априла, опаском да су вести о миру изазвале немир у Сенату. ${ }^{22}$

Овај период обележен је приближавањем Енглеској у којој је Сенат пронашао савезника, у време када су односи са Бурбонима били затегнути. ${ }^{23}$ Исту чињеницу је Кристијан Кол препознао и као повољну прилику за потписивање трговачког уговора са Венецијом, који би енглеској роби обезбедио повољно тржиште. Овим је енглески представник спекулисао када је постала очигледна чињеница да су Црногорци спремни на устанак ако Порта зарати са Русима, што би по Коловим проценама могло изазвати немир у Которском заливу. ${ }^{24}$ У време када је о томе јављао у Лондон, млетачка флота стајала је усидрена у Новом. ${ }^{25}$ Почетком маја Сенат је изабрао за генералног провидура Далмације и Албаније, ${ }^{26}$ са 136 гласова за

\footnotetext{
${ }^{14}$ Детаљан попис литературе која се односи на овај сукоб у: Calvin Dickinson - Elois Hitchcock, The War of the Spanish Succession, 1702-1713: a selected bibliography, Westport 1996.

${ }^{15}$ NAL, SP, 99/60, f $65 \mathrm{v}$; Венеција, 24. III 1713.

${ }^{16} \mathrm{NAL}, \mathrm{SP}, 99 / 60, \mathrm{f}^{\circ} 67 \mathrm{v}$; Венеција, 24. III 1713; друго писмо са истим датумом.

${ }^{17}$ NAL, SP, 99/60, fo 75r; Венеција, 31. III 1713. Оштећено место на документу на коме се налази нумерација фолија.

${ }^{18}$ NAL, SP, 99/60, f $75 \mathrm{r}$

${ }^{19}$ NAL, SP, 99/60, f $86 \mathrm{v}$; Венеција, 21. IV 1713.

${ }^{20}$ NAL, SP, 99/60, fo 88v; Венеција, 21. IV 1713; друго писмо под истим датумом.

${ }^{21}$ Monthly Mercury, vol. XXIV... For the Month od April, 137.

${ }^{22}$ NAL, SP, 99/60, f 92v; Венеција, 28. IV 1713.

${ }^{23}$ NAL, SP, 99/60, fo 97r; Венеција, 5. V 1713.

${ }^{24}$ NAL, SP, 99/60, fo 107r; Венеција, 12. V 1713.

${ }^{25} \mathrm{NAL}, \mathrm{SP}, 99 / 60, \mathrm{f}^{\circ}$ 106v-107r. Данашњи Херцег Нови кога је млетачка војска уз подршку локалног становништва и хајдука успела да освоји 30. септембра 1687, након опсаде која је трајала готово месец дана. Марија Коцић, Венеција и хајдуци у доба Морејског рата, Београд 2013, 264-275.

${ }^{26}$ Provveditore Generale di Dalmatia et Albania - генерални заповедник војске и флоте у Далмацији и Млетачкој Албанији. Њему су били потчињени сви ванредни и редовни провидури именовани у овим областима. Краће време током Првог морејског рата (1684-1699) када су у последњој фази овог сукоба аспирације Венеције биле везане за Херцеговину, овој титули додаје се и наведена област (Provveditore Generale di Dalmatia et Albania et Herzzegovina).
} 
и 100 против, Анђела Ема, који је требало да замени Карла Пизанија, чија је служба истекла. ${ }^{27}$ Његов избор одвијао се у атмосфери нових убистава. Једна жена убијена је почетком маја, а друга изјутра 12 . маја, а убицу није стигла казна. ${ }^{28}$

Крајем маја дугоочекивани саксонски изборник стигао је у Венецију. Он је инкогнито 25. маја присуствовао традиционалној свечаности „женидбе дужда са морем“. ${ }^{29}$ За њега се претпостављало да ће током целог лета остати у Венецији, јер је изнајмио кућу у овом граду. ${ }^{30}$ Кристијан Кол у овоме греши, јер је реч о сину саксонског изборника. Наиме, изборнику Саксоније Фредерику Августу I Јаком $(1694-1733)^{31}$ пошло је за руком да у борби за пољски престо однесе победу над осталим кандидатима и буде крунисан за новог владара (1697), уз претходно положену заклетву да ће из протестантске прећи у католичку веру. У Венецију је у лето 1713. године стигао његов син Фредерик Август. Он је, следећи очев пример, у Болоњи, 28. новембра 1712, био покрштен у католичку веру, да би потом посетио Рим. ${ }^{32}$

Током јуна 1713. у Венецији није било значајних дешавања. У штампи се једино помињу мере Сената на заштити од куге, која је пустошила по Угарској. Поред тога, њену пажњу заокупљао је боравак саксонског кнеза, за кога није било

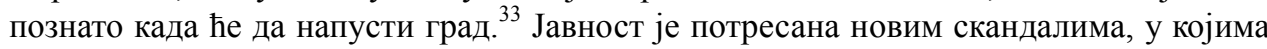
су учествовали и припадници виших слојева друштва. Племић из старе племићке породице Минио доспео је у затвор због крађе и пљачке неколико кућа. ${ }^{34}$ Жртва непознатог нападача постала је позната куртизана Тромпетина, у тренутку док се спремала да се искрца из гондоле, испред улазних врата куће у којој је становала. На cрећу, метак ју је промашио. ${ }^{35}$ У атмосфери низа нерешених напада и разбојништава, Сенат је већао о потреби да врати стару вредност новцу. ${ }^{36}$ Формиран је засебан Комитет, ${ }^{37}$ у чему су консултовани Веће за трговину (Cinque Savii alla Mercanzia) ${ }^{38}$ и сродни магистрати. ${ }^{39}$ Пооштрене су и мере за увоз стоке и робе из

\footnotetext{
${ }^{27}$ NAL, SP, 99/60, fo 106v.

${ }^{28}$ NAL, SP, 99/60, fo 109v; Венеција, 12. V 1713; друго писмо под истим датумом.

${ }^{29}$ NAL, SP, 99/60, fo 113r; Венеција, 26. V 1713.

${ }^{30}$ NAL, SP, 99/60, fo $117 \mathrm{r}$; Венеција, 2. VI 1713.

${ }^{31}$ О овом владару литература је углавном на немачком језику. Вид.: Karl Czok, August der Starke und seine Zeit. Kurfürst von Sachsen und König von Polen, Munich 2006. Значајни биографски подаци о њему објављени и у: Heinrich Theodor Flathe, Friedrich August I., Kurfürst von Sachsen, Allgemeine Deutsche Biographie, vol. VII, Leipzig 1878, 781-784.

${ }^{32}$ Када је стигао у Италију, имао је свега 16 година (рођен је 1696). Наследио је оца на положају изборника Саксоније 1733. и владао до 1763. као Фредерик Август II. О његовој владавини детаљније у: Jacek Staszewski, August III. Kurfürst von Sachsen und König von Polen, Berlin 1996. Основни биографски подаци у: Heinrich Theodor Flathe, Friedrich August II., Kurfürst von Sachsen, Allgemeine Deutsche Biographie, VII, 784-786.

${ }_{33}^{33}$ Monthly Mercury, vol. XXIV. For the Month od June, 229.

${ }^{34}$ NAL, SP, 99/60, fo 119r; Венеција, 9. VI 1713.

${ }^{35}$ NAL, SP, 99/60, f $125 \mathrm{r}$; Венеција, 16. VI 1713.

${ }^{36}$ NAL, SP, 99/60, fo 130v; Венеција, 30. VI 1713.

${ }^{37}$ Кол га наводи као Комитет, мада је заправо била реч о новом колегијуму.

${ }^{38}$ Веће пет сенатора за трговину, како би се могао превести назив обе установе у дословном смислу, основано је одлуком Сената 15. јануара 1507, а 10 година касније постало је стално тело. У његов делокруг спадали су послови који су се тицали трговине и пловидбе, као и расписивање дажбина, које су се односиле на ове делатности. У случају трговачких спорова између млетачких и страних трговаца
} 
Немачке, Шлезије и Моравске. Увоз робе из наведених области забрањен је под претњом смртне казне. ${ }^{40}$

Долазак лета нагонио је становнике Венеције, посебно оне бољег имовног стања, да напусте град и преселе се у пријатну сеоску средину. И Ђанбатиста Касоти се спремао да напусти град, рачунајући да ће му сељани „указати хиљаде почасти“. ${ }^{41}$ Њему је у то време Венеција деловала лепо, док су га њени становници подсећали на Париз. ${ }^{42}$ Изгледа да се Касоти није дуго задржао на селу. По повратку у Венецију, присуствовао је свечаности приређеној на дан Санта Марине, коју су Млечани славили од времена освајања Падове 1509 . године. ${ }^{43}$ У овој свечаности узели су учешће дужд, Ђовани II Корнаро (1709-1722), и папски нунције у пратњи других угледних људи из власти и цркве, укупно 50 племића, али не и амбасадор Карла VI. ${ }^{44}$

Првих дана јула у Венецију се вратио прокуратор Лоренцо Тјеполо, амбасадор до тада на служби у три европске престонице - Паризу, Бечу и Риму. ${ }^{45}$ Њему је Сенат обезбедио свечани улазак у град, где је поводом овог догађаја проглашен маскенбал. ${ }^{46}$ Славље није скренуло пажњу елите са прилика у којима се држава нашла. У најзначајнијем телу, Сенату, владало је натегнуто расположење створено надмудривањима сукобљених струја. У таквој клими Пјетро Гарцони, аутор Историје Свете лиге, ${ }^{47}$ предложио је да се из Утрехта опозове Карло Руцини, ${ }^{48}$ који по његовом суду ништа није успео да уради у одбрани млетачких интереса. Намеру Пјетра Гарцонија оспорили су други сенатори, због чега у погледу опозива Руцинија ништа није одлучено. ${ }^{49}$ Након што је Сенат добио нове вести из Низоземске, престао је да се бави опозивом Руцинија. ${ }^{50}$ Две недеље касније, међутим, након неколико дебата у Сенату, донета је одлука о његовом опозиву. ${ }^{51}$

имало је право да интервенише и доноси одлуке. Законом од 7. марта 1586. поверен му је и избор конзула у факторијама (трговачким колонијама).

${ }_{39}$ NAL, SP, 99/60, fo 132v; Венеција, 30. VI 1713; друго писмо под овим датумом.

${ }^{40}$ NAL, SP, $99 / 60, f^{\circ} 133 \mathrm{r}$.

${ }^{41}$ Da Venezia nel 1713. Lettere di Giovambatista Casotti Accademico della Crusca a Carlo Tommaso Strozzi e al Can[onico] Lorenzo Gianni, Prato 1866, 7; писмо од 7. VII 1713.

${ }^{42}$ Исто, 7.

${ }^{43}$ Исто, 12; писмо од 17. VII 1713.

${ }^{44}$ Исто, 12

${ }^{45}$ NAL, SP, 99/60, fo 138r; Венеција, 14. VII 1713. О њему вид. и: Da Venezia nel 1713. Lettere di Giovambatista Casotti, 7-8; писмо од 10. VII 1713.

${ }^{46}$ NAL, SP, 99/60, f ${ }^{\circ}$ 140r; Венеција, 14. VII 1713; друго писмо под овим датумом.

${ }^{47}$ Пун наслов овог дела гласи: Istoria della Repubblica di Venezia in tempo della Sacra Lega Contra Maometto IV, e tre suoi Successori. Доживело је велику популарност у Венецији, као и у ондашњој културној и научној јавности. Најзначајнија издања су из 1705. и 1707. да би поново била објављена 1720 (Appresso Gio: Manfrè).

${ }^{48}$ Карло Руцини (Carlo Ruzini) био је представник Венеције на преговорима у Карловцу (данашњи Сремски Карловци) коме и поред натезања са медијаторима и Портиним преговарачима није пошло за руком да за рачун своје државе сачува освојене територије. Вид. и: М. Коцић, Венеција и хајдуци, 385-388. Овде је наведена додатна литература. У време када је боравио у Утрехту, Руцини је уживао титулу прокуратора и сенатора. Настојање Гарцонија да се Руцини повуче из Утрехта није га спречило да у другој својој књизи велича његов лик и дело, алудирајући на кредибилитет који је стекао у Карловцу (1698-1699); P. Garzoni, Istoria della Repubblica di Venezia, 784.

${ }^{49}$ NAL, SP, 99/60, fo 149r; Венеција, 28. VII 1713.

${ }^{50}$ NAL, SP, 99/60, fo 151v; Венеција, 28. VII 1713; друго писмо под овим датумом.

${ }^{51}$ NAL, SP, 99/60, fo 158v; Венеција, 11. VIII 1713. 
Саксонски кнез, који је до тада боравио инкогнито у граду, одлучио је да се појави у јавности. У ту сврху Сенат је именовао Трона, Моченига, Кверинија и Пизанија, „све младе људе великог богатства“ у његову пратњу. ${ }^{52}$ Став који су млетачке власти заузеле према сину саксонског изборника потицао је из заслуга које је Саксонија имала за млетачку војску у претходном рату са Турцима. Већ 1684. године војници регрутовани у том Војводству почињу да служе у млетачкој војсци, ${ }^{53}$ и то углавном у операцијама на Мореји. С тим је настављено и наредних година.

Велики канцелар ${ }^{54}$ Пјетро Бусинело преминуо је после краће болести 6. августа, након 14 година, 9 месеци и 2 дана службе на том положају. ${ }^{55}$ Сахрањен је 7. августа, а наредног дана Велико веће било је сазвано ради избора његовог наследника. За овај положај кандидовала су се три сенатора, чија имена Кол не наводи. ${ }^{56}$ Касоти је, међутим, забележио да су се надметали петорица кандидата (Гратариол, Алберти, Имберти, Зон и Николози). Ускоро су њих тројица повукла кандидатуру, тако да се избор свео на Албертија и Николозија. ${ }^{57}$ Великом већином изабран је Ђовани Батиста Николози, цењен од Кристијана Кола као човек великог угледа, у доби од 73 године, и слабог здравља. У част његовог избора приређен је маскенбал у трајању од три дана. ${ }^{58}$ Неколико дана касније (17. августа) статуа начињена према лику Бусинела, обучена у свечану одору, истакнута је у Цркви Св. Марка, где је наредног дана одржан говор у његову част. Она је истог поподнева у пратњи дужда, Ђованија II Корнара, племства, папског нунција и амбасадора Карла VI ношена на тргу око Цркве Св. Марка, а потом је пренета у Цркву Св. Јована и Павла. Како је Кол забележио, ова церемонија није се много разликовала од оне примењиване у случају смрти дужда, или страног амбасадора. ${ }^{59}$

Крајем августа отворена је у Венецији лутрија. Одштампано је 60.000 тикета у вредности 2 дуката по листићу, на основу чега је требало бити сакупљено 120.000 дуката (око 20.000 фунти стерлинга). ${ }^{60}$ Расписивање државне лутрије, на основу које би била прикупљена одређена средства, није било случајно, већ је представљао знак кризе финансијског система. На ово указују и полемике у Сенату вођене средином септембра, на којима се расправљало о сиромаштву које је завладало у Републици. Том приликом требало је размотрити мере о отплати камата на државни зајам у условима када у благајни није било новца. Током заседања поједини сенатори предлагали су да се смањи камата од 5\% на 2-3\% на основу дукала, који би сам Сенат донео. ${ }^{61}$ Кол наводи да би усвајањем ове мере била нанета

\footnotetext{
${ }^{52}$ NAL, SP, 99/60, fo 149 r.

${ }^{53}$ М. Коцић, Венеција и хајдуц̧и, 177.

${ }^{54}$ Ђамбатиста Касоти ову дужност помиње као: Cancellier grande, o il Cancelier di Venezia; Da Venezia nel 1713., 18; писмо од 12. VIII 1713.

${ }^{55}$ Исто, 22; писмо од 26. VIII 1713.

${ }^{56}$ NAL, SP, 99/60, f $158 \mathrm{v} ;$ Венеција, 11. VIII 1713.

${ }^{57}$ Da Venezia nel 1713., 19; писмо од 12. VIII 1713.

${ }^{58}$ NAL, SP, 99/60, fo $158 \mathrm{v}$.

${ }^{59}$ NAL, SP, 99/60, f ${ }^{\circ} 162 \mathrm{v}-163 \mathrm{r}$; Венеција, 18. VIII 1713.

${ }^{60}$ NAL, SP, 99/60, fo 167v; Венеција, 25. VIII 1713.

${ }^{61}$ NAL, SP, 99/60, fo 188v; Венеција, 15. IX 1713.
} 
„велика неправда свим кредиторима“. ${ }^{62}$ Наредних неколико дана у Сенату је о томе трајала дебата, а на крају се одустало од редукције камате за државне зајмове. ${ }^{63}$

Крајем месеца син саксонског изборника планирао је да напусти Венецију, ${ }^{64}$ док је новом великом канцелару, Николозију, приређено свечано представљање у јавности. Карло Руцини, након што је опозван неколико недеља раније, налазио се недалеко од Вероне, где је требало да проведе 40 дана у карантину. ${ }^{65}$ Ускоро је почео „велики одмор“, због чега је распуштено Велико веће. ${ }^{66}$ Руцини је стигао 9. новембра након издржаног карантина у Венецију, истог дана када и нови папски нунције, кардинал Алдобрандини. ${ }^{67}$

Крајем 1713. наступила је хладна зима, готово иста као и претходна. У писму од 8. децембра Кол наводи да је снег, који је падао протеклих пет дана, прекрио целу Венецију и Тераферму. Никакви од значаја догађаји нису ометали временом наметнуту летаргију, сем одлука Сената да се разоружају и уклоне све галеаце из Арсенала, под изговором да је њихово одржавање скупо, и да у Венецији нико не уме да управља њима. ${ }^{68}$ Почетком јануара 1714. Сенат је донео одлуку да се наставе добри односи са Карлом VI „по сваку цену“ и да се убудуће делује у складу с њим. Ово је, судећи по писању Кристијана Кола, одлучено јер су Турци доживљавани као заједничка претња. Сенат је изабрао посланике који је требало да отпутују у Беч и да са том одлуком упознају Карла VI. ${ }^{69}$ Дуго отезане несугласице са Ватиканом, због пловидбе и транспорта соли реком По, биле су решене. У том тренутку за највећег противника Венеције словио је нови краљ Сицилије, војвода Савоје Виторио Амадео II. $^{70}$ Тумачећи дешавања у Венецији, Кристијан Кол наводи да је она запала „у савршену олигархију“, за коју процењује да је „најгора од свих влада“, састављена од људи у чијим су рукама били сав новац и власт. ${ }^{71}$

Карневал је те године окончан 8. фебруара. Наредног дана се дужд у свечаној процесији и у пратњи амбасадора Карла VI појавио пред својом палатом, недалеко од Цркве Св. Марка. ${ }^{72}$ Карневалска атмосфера није могла власт задуго да лиши актуелних проблема. Крајем месеца Карло VI јавио је Сенату о обимним војним припремама Турака, што је било знак да се алармира цела млетачка јавност. ${ }^{73}$ Судећи по писању штампе, томе је допринело понашање Портиних службеника

\footnotetext{
${ }^{62}$ NAL, SP, 99/60, fo 191r; Венеција, 15. IX 1713.

${ }^{63}$ NAL, SP, 99/60, fo 194v; Венеција, 22. IX 1713.

${ }^{64}$ До овога је дошло тек средином октобра; NAL, SP, 99/60, fo 209r; Венеција, 13. X 1713.

${ }^{65}$ NAL, SP, 99/60, fo 198v-199r; Венеција, 29. IX 1713.

${ }^{66}$ Consiglio Maggiore - теоретски је представљао нисиоца суверенитета Венеције. Овакво стање de facto постојало је од XIII века а de iure прихваћено 1423. Детаљније у: William Bouwsma, Venice and the Defense of Republican Liberty. Renaissance Values in the Age of the Counter Reformation, Berkeley - Los Angeles 1968, 60-61. Из редова Великог већа бирани су чланови Сената, којих је било око 300.

${ }^{67}$ NAL, SP, 99/60, fo 231v; Венеција, 10. XI 1713.

${ }^{68}$ NAL, SP, 99/60, f ${ }^{\circ}$ 243r; Венеција, 8. XII 1713.

${ }^{69}$ NAL, SP, 99/60, fo 266v; Венеција, 5. I 1714.

${ }^{70}$ NAL, SP, 99/60, f $\mathrm{f}^{\circ}$ 264v-265r; Венеција, 12. I 1714. О овом владару детаљније у: Christopher Storrs, War, diplomacy and the rise of Savoy, 1690-1720, Cambridge 1999; Geoffrey Symcox, Victor Amadeus II: absolutism in the Savoyard State, 1675-1730, Berkeley - Los Angeles 1983.

${ }^{71}$ NAL, SP, 99/60, fo 267r; Венеција, 5. I 1714.

${ }^{72}$ NAL, SP, 99/60, f 279r; Венеција, 8. II 1714.

${ }^{73}$ NAL, SP, 99/60, f ${ }^{\circ}$ 285r; Венеција, 23. II 1714.
} 
током аудијенције млетачког баила одржане 15. јануара 1714. Наиме, баила је дочекао велик број наоружаних војника, што није био обичај, осим када је Порта планирала да са одређеном државом зарати. Генерални став који је заузела штампа био је, међутим, да Порта још увек није у прилици да прекине мир са Венецијом. ${ }^{74}$

Првих недеља априла расписана је лутрија у вредности, прерачунатој у енглеској валути, 240.000 фунти стерлинга. Млетачке власти су захтевале и од енглеских трговаца, који су пословали у Венецији, да купују ове тикете. ${ }^{75}$ Лутрија је, и поред намере власти да на тај начин прикупи новац, пружала сваком учеснику право на добитак, због чега су листиће куповали и најнижи слојеви друштва. На јавном извлачењу, организованом 27. априла, главна премија припала је неком сиромашном пекару. ${ }^{76}$

Почетком маја амбасадор Карла VI у овој држави, кнез Херколани, вратио се из Болоње, где је боравио једно време. У том тренутку Кристијан Кол располагао је информацијама да он планира повратак у Беч, због чега је припремана опроштајна аудијенција. ${ }^{77}$ За његовог наследника одређен је гроф Колоредо. ${ }^{78}$ У исто време Магистрато але Помпе (Magistrato alle Pompe) ${ }^{79}$ објавио је указ против раскошне одеће и забава. ${ }^{80}$

Крајем маја расписана је нова лутрија, чиме је држава намеравала да сакупи пола милиона дуката. Вредност тикета остала је иста - два дуката. Ова је лутрија по пропозицијама личила на Велику лутрију расписану у Низоземској. Књиге је требало да буду отворене 1. јуна, док је за дан извлачења главне премије одређен 1. фебруар $1715 .^{81}$ Вест о томе објављена је и у штампи, у којој је наведено да је Сенат објавио дукал о „новој лутрији“ од 500.000 дуката, односно 250.000 тикета. Лутрија расписана у Венецији оцењена је бољом од низоземске, која је имала мањи број награда. ${ }^{82}$

Расписивање државне лутрије привукло је пажњу Кристијана Кола, који је у више докумената о томе јављао у Лондон. Он је „моделом“ млетачке лутрије био

\footnotetext{
${ }^{74}$ Monthly Mercury, vol. XXV...For the Month of March, 84. Међутим, у једном извештају Кристијан Кол наводи супротну чињеницу. Наиме, да је брод који је у Венецију стигао из Цариграда донео вест да је баило Емо врло добро био примљен на Порти; NAL, SP, 99/60, fo 310r; Венеција, 6. IV 1714.

${ }^{75}$ NAL, SP, 99/60, fo $314 \mathrm{v}$; Венеција, 13. IV 1714.

${ }^{76}$ NAL, SP, 99/60, f ${ }^{\circ}$ 319v; Венеција, 27. IV 1714.

${ }^{77}$ NAL, SP, 99/60, fo 321r; Венеција, 11 V 1714.

${ }^{78}$ Monthly Mercury, vol. XXV. For the Month of May, 169-170.

79 Заметак поменутог магистрата представљао је избор Tre Savij alle Poтре 1476. Међутим, ова установа није била дугов века и ускоро је престала да постоји, до 1514, када је поново уведена, овог пута у форми посебне Магистратуре. Установа Седам сенатора Колегијума за свечаности (Sette Savi dil Colegio ale Pompe) неретко се у документима јавља под називом Колегио але Помпе (Collegio alle Pompe). Деловала је под утицајем магистрата основаног у циљу регулисања процесија, свечаности и јавног реда и мира (Magistrato alle Pompe), на чијем су се челу налазили провидури и натпровидури (Provveditori e Sopraprovveditori alle Pompe). Ово тело имало је надзор и над новцем предвиђеним у сврху организовања свечаности, пријема и осталих светковина. Настала је на основу више одлука донетих 1651. и 1652, да би одлуком Великог већа од 11. фебруара 1652. био предвиђен избор 7 сенатора у оквиру наведеног колегијума.

${ }^{80}$ NAL, SP, 99/60, fo $321 \mathrm{r}$

${ }^{81}$ NAL, SP, 99/60, fo 340v; Венеција, 25. V 1714

${ }^{82}$ Monthly Mercury, vol. XXV...For the Month of May, 170.
} 
више фасциниран него низоземским. Међутим, његова преписка срачуната је на то да објасни властима у Енглеској начин њене организације, али је праве узроке, који су довели до њеног расписивања, у својим писмима заобишао. Ова појава до данас привлачила је малу пажњу историчара, чак и оних који се баве економском историјом. На први поглед не може се заобићи утисак да је расписана у тренуцима кризе, која је погодила цело млетачко друштво, с намером да држава дође до новца. С друге стране, Кол не доводи њено увођење у везу с ратом, који је био на помолу. На тај начин постављен проблем открива другу реалност млетачког привредног система - недостатак готовог новца, који је био у директној вези с кризом капитала.

Истраживања историчара који су се бавили економском историјом Венеције крајем XVII и почетком XVIII века указују да је у поменутом периоду патрицијат увелико улагао новац у куповину земљишних поседа у Тераферми, ${ }^{83}$ у околностима када је цена житу драстично опала у свим деловима Западне Европе, укључујући и Италију. ${ }^{84}$ Фернан Бродел као један од разлога „преусмеравања“ млетачког капитала наводи пиратерију, која је овладала Средоземљем. ${ }^{85}$ На овај начин постављен проблем указује да су ове инвестиције представљале „промашај“, у околностима када је требало наћи бољи начин за улагање капитала. Непродуктивна инвестиција за собом је носила ризик мањка расположивог новца, што је свакако погодило не само владајућу структуру Венеције, већ је довело до монетарне кризе у овој држави. Ово је по Стјуарту Волфу отварало други проблем: „одакле је долазио капитал којим је купована земља?““ Остављајући могућност да је током претходног периода његово извориште била трговина, Волф за капитал с почетка XVIII века (када Венеција више није била трговачка сила) нагађа да је стваран на основу приватних зајмова на које је узимана камата. ${ }^{86}$ Тиме се долази до закључка у вези са увођењем државне лутрије у друштву које је, губећи позиције трговачке силе, настојало да разним монетарним манипулацијама оствари извесне приходе (донекле слична ситуација са Низоземском). Проблем који су дотакле раније генерације историчара (уз ограду да државној лутрији у Венецији до данас није посвећена значајна пажња) Кол потпуно прећуткује у извештајима, определивши се за једноставну интерпретацију исхода на овај начин наметнуте махинације капиталом - креирања додатних прихода за државну благајну.

Ранија нагађања Кола о смени дипломатског представника Карла VI у Венецији ускоро су се показала тачним. Првог дана јуна кнез Херколани добио је од Сената златан ланац са медаљоном, који је вредео 200 фунти стерлинга, на име

\footnotetext{
${ }^{83}$ О изгледу и функционисању ових сеоских имања вид.: Fernan Brodel, Materijalna civilizacija, ekonomija $i$ kapitalizam od XV do XVIII veka, vol. I-III, Beograd - Novi Sad 2007, II [Igre razmene], 271-272.

${ }^{84}$ Stuart Woolf, "Venice and the Terraferma: Problems of the Change from Commercial to Landed Activities", y: Brian Pullan (ed.), Crisis and Change in the Venetian Economy in the Sixteenth and Seventeenth Centuries, London 1968, 175-203, 200. Бродел је, међутим, супротног схватања и наводи: „Управо је раст цена аграрних производа и профита подстакао млетачки капитал према земљи“. F. Brodel, Materijalna civilizacija, ekonomija i kapitalizam, II, 272. Његова констатација односи се, међутим, на каснији период (XVIII век).

${ }^{85}$ F. Brodel, Materijalna civilizacija, ekonomija i kapitalizam, II, 272.

${ }^{86}$ S. Woolf, "Venice and the Terraferma", 200.
} 
поклона, за дужности коју је обављао. ${ }^{87}$ Тиме је уважена процедура практикована у случају одласка амбасадора. Ускоро је Херколани напустио Венецију и отпутовао у Болоњу, одакле је требало да продужи за Беч. ${ }^{88}$

У атмосфери оскудице, напетости и све очигледнијег безнађа није се одустајало од сваке погодне прилике за славље. Почетком јуна, на Дан Светог Антонија, дужд, свештенство Венеције и папски нунције посетили су у свечаној поворци Цркву Санта Мадона дела Салуте (Santa Madona della Salute), ${ }^{89}$ у којој је одржана служба у част поменутог свеца. Иста поворка је 15. јуна изјутра посетила Цркву Сан Вито (San Vito) „у сећању на заверу“. Потом је дужд приредио банкет, на коме је дозвољено ношење маски. ${ }^{90}$ Убрзо је за дужда уследило неочекивано разочарење. У Мирандоли је изненада дошло до експлозије 300 буради ускладиштеног барута. Том приликом уништен је цео бастион, а штету су претрпели и дуждева палата, оближњи конвент и околне куће. Страдало је 300 људи, док је за губитке Кол претпоставио да ће их Венеција тешком муком моћи надокнадити. ${ }^{91}$

Лето, које је било изузетно топло у Граду Св. Марка, ${ }^{92}$ протицало је у наизглед перфектном функционисању управног апарата, док се над Медитераном надвијала опасност новог рата. Почетком јула грчка шајка, која је упловила у млетачку луку, донела је вест да је пет малтешких галија кренуло у потеру за турским бродовима. ${ }^{93}$ Убрзо су Малтежани почели да шире вести да су њихови бродови наишли на велику флоту турских ратних бродова. Појединци су чули гласине, које су дошле и до Кристијана Кола, да ова флота планира да се искрца у Италији. ${ }^{94}$

Инфекција потакнута великом врућином изазвала је нови талас помора стоке на Апенинском полуострву који није заобишао ни Венецију. Здравствени магистрат ${ }^{95}$ је, разматрајући велики помор који је захватио крупну стоку у Млетачкој републици, издао прокламацију којом је био забрањен увоз стоке из области заражених сточном кугом. Такође, за пребацивање стоке из једног места у друго захтевана је болета о њеном здравственом стању. ${ }^{96}$ На тај начин Венеција је покушала да заштити своју територију од сточне куге, која је на Полуострву у налетима била присутна неколико последњих година. ${ }^{97}$

\footnotetext{
${ }^{87}$ NAL, SP, 99/60, f ${ }^{\circ}$ 342v; Венеција, 1. VI 1714.

${ }^{88}$ NAL, SP, 99/60, fo 346r; Венеција, 8. VI 1714.

${ }^{89}$ Кол овде греши. У питању је базилика Санта Мадона дела Салуте - која се налази у сестијеру Дорсодуро. Она није била издвојена у посебну парохију, већ је припадала парохији Giesuati. У време Франческа Сансовина није постојала. F. Sansovino, Venetia. Città Nobilissima, 270-271. Посебно је била посећивана у време куге, што датира још из 1630.

${ }^{90}$ NAL, SP, 99/60, fo 348r; Венеција, 15. VI 1714.

${ }^{91}$ NAL, SP, 99/60, f $0353 \mathrm{v} ;$ Венеција, 22. VI 1714.

${ }_{92}^{2}$ NAL, SP, 99/60, fo 366r; Венеција, 20. VII 1714.

${ }^{93}$ NAL, SP, 99/60, f 0 360r; Венеција, 6. VII 1714.

${ }^{94}$ NAL, SP, 99/60, fo 368v; Венеција, 27. VII 1714.

${ }^{95}$ О пореклу ове установе вид.: Marija Kocić, Razvoj zdravstvene službe u Veneciji (Magistrato alla Sanità), Acta historiae medicinae, stomatologiae, pharmaciae, medicinae veterinariae, н. с., 1, 2013, 41-51. Овде је наведена сва додатна литература.

${ }^{96}$ NAL, SP, 99/60, fo 376r; Венеција, 3. VIII 1714.

${ }^{97}$ Clive A. Spinge, Cattle Plague. A History, New York 2003, 103-104; Mauro de Zan, Un esempio di collaborazione scientifica: l' edizione dell' opuscolo, y: Maria Teresa Monti (ed.), Nuova Idea del Male
} 
Септембра Кристијан Кол спремао се за повратак у Енглеску, дочекавши да прими уобичајене поклоне од Сената. У време када је напуштао Венецију, штампу су занимали њени односи са Портом. Уговор у Раштату ${ }^{98}$ имао је последице и на односе Порте са Хабзбурговцима, због чега је позван представник Беча на разговор код великог везира. Повод је био страх Порте од могућег погоршања прилика у Угарској, након што је немачка војска била растерећена од ратовања са Француском. ${ }^{99}$

С јесени 1714. постала је извеснија намера Порте да објави рат Венецији. На то су указивали извештаји амбасадора Енглеске у Цариграду, Роберта Сутона (1701-1717). У ту сврху Порта је наредила изградњу и обнову магацина у Солуну и Лариси, намењених складиштењу оружја и провијанта. Исте мере преузете су на Негропонту (Еубеја). Бродовима који су превозили робу за Египат наређено је да остану у Галати. Решено је да се регрутују 15.000 левенти и да 9 (односно 12) ода јаничара буду прекомандоване из Хоћина на Негропонт. На основу тих одлука, по тумачењу Роберта Сутона, многи су били убеђени да ће султан наредног пролећа решити да нападне млетачке поседе на Мореји (Пелопонез). ${ }^{100}$

Како је месец дана касније Сутон јавио у Лондон, велики везир и поједини достојанственици на Порти били су против рата с Венецијом. Настојао је да прикаже ову одлуку као лични султанов хир. Међутим, није се могао отети утиску да су становници Цариграда негативно настројени према Млечанима, јер су „без икакве провокације“ пришли Светој лиги у претходном рату. ${ }^{101}$ Већ дефинисано негативно расположење искоришћено је у оправдању одлуке да објави рат Венецији. Највише је у интересе Порте задирала одлука локалних млетачких власти да пруже уточиште Црногорцима. ${ }^{102}$ На томе би и остало да Порта није тражила сваки, па и

Contagioso de'Buoi', L'edizione del testo scientifico in età moderna. Atti del Seminario di studi (Scandiano 10 12 ottobre 2001), Firenze 2003, 55-73, 56-57. Извештаје појединих медикуса са универзитета у Падови, које је Сенат овластио да изврше испитивање: Tommaso Bottari, Delle epizoozie, ossia delle epidemie contagiose e non contagiose che influirono negli animali utili principalmente all'agricoltura, del Veneto Dominio o in Italia, vol. I-II, Venezia 1819, vol. II, објављен под насловом Consulta fatta dalli Professori eletti del Sacro Collegio de' Filosofi e Medici l'anno 1711 il dì 28 settembre d'ordine pubblico. О помору стоке у претходном периоду у Венецији вид. трактат: Antonio Borromeo - Giovanni Maria Lancisi, Istoria dell'Epidemia de' Buoi accaduta l'anno 1711 con l'esame delle cagioni, uso de' Remedi e modo di preservare $i$ Buoi sani, Padova 1712.

${ }_{98}$ P. Garzoni, Istoria della Repubblica di Venezia, 808-814. Најдетаљьиији извештај припада Казимиру Фрескоту и третира све околности које су довеле до ових преговора: Casimir Freschot, Histoire du Congres et de la Paix d'Utrecht, comme aussi de celle de Rastadt \& Bade, Utrecht 1716. О Фрескотовом приказу преговора и значају дела вид.: Heinz Duchhardt, Die Systematisierung und Typologisierung des Friedens. Das Vorwort von Casimir Freschots „Histoire du Congres et de la Paix d'Utrecht, comme aussi de celle de Rastadt \& de Bade“, y: Heinz Duchhardt - Martin Spenhorst (ed.), Utrecht - Rastatt-Baden 1712-1714: Ein europäisches Friedenswerk am Ende des Zeitalters Ludwigs XIV, Gottingen 2013, 303-312.

${ }_{99}$ Historical and Political Monthly Mercury, vol. XXV... For the Month of September, 345. О карактеру хабзбуршке политике на Порти у овом периоду: Maria Baramova, Der Frieden von Baden und seine Deutung am Golden Horn. Die Kaiserliche Diplomatie in Konstantinopel (1713-1715), y: Duchhardt - Spenhorst, Utrecht - Rastatt-Baden 1712-1714, 357-372.

${ }^{100}$ NAL, SP, 97 [Turkey] / 23 [Sir Robert Sutton, 1713-1716], fo 116; Пepa, 7. X 1714.

${ }^{101}$ NAL, SP, 97/23, fo 117v-118r; Пера, 26. ХІ 1714. О приступању Венеције Светој лиги 1684. вид.: М. Коцић, Венещија и хајдуции, 66-75. Овде је наведена додатна литература.

102 На ово није указано само у домаћој историографији већ су и неки страни историчари сматрали побуну Црногораца као главни повод који је навео Порту да објави рат Венецији. Kenneth M. Setton, Venice, 
најбизарнији, повод да објави рат Сенату.

Сенат је на вести из Цариграда, које су га опомињале да је рат неизбежан, приступио наоружању и опремању војске и морнарице. Штампа је објавила да је наређена хитна поправка бродова у Арсеналу. Рачунало се да ће Венеција почетком пролећа располагати са 24 ратна брода, 4 галеаца и 24 галије, поред већег броја мањих пловила. Очекивало се да ће папа помоћи одређеним бројем бродова, као и Малта. Мали број војника из Тераферме био је предвиђен за слање у Далмацију. Отпочели су преговори о врбовању 7.500 саксонских војника, 3.000 у Витембергу и 2.000 Швајцараца. Издато је одобрење за врбовање 3.000 Италијана и регрутовање раније распуштених регименти. ${ }^{103}$ Наведене мере доказују да је Сенат прихватио наступајући рат као реалност, која се ничим није могла избећи.

У списима Кристијана Кола помињу се догађаји од значаја за друштвену историју Венеције ове епохе. Њему нису промакли злочини, чији су починиоци припадници њене владајуће структуре. Имена куртизана које се јављају у његовој преписци откривају да је Кол био упознат са овом појавом млетачке свакодневице, која је успела да опстане вековима. Релативно добро познавање прилика у патрицијату Кол је допунио и извештајима о увођењу државне лутрије 1714, при чему је Венеција следила „низоземски модел“, настојећи да га унапреди. На том пољу његови извештаји су најбољи извор немлетачке провенијенције за њено праћење.

Заседања Сената на којима су доношене одлуке од државног значаја нашла су значајно место у његовим писмима, а такође и личности које су у овом периоду посетиле Град Св. Марка. Године 1713-1714. обележене су преговорима у Утрехту и Раштату, који су креирали нову политичку карту Европе, дефинишући границе које су опстале наредних деценија (до 1746). Продор Аустрије у Италију један је од најзначајнијих њихових исхода, што није могло Венецију да остави по страни. Ставови према актуелним дешавањима нашли су одјек у извештајима које је слао у Енглеску, и засновани су на властитом углу посматрања.

Венеција Кристијана Кола представља град задубљен у сопствену величину, са свакодневицом утомљеном у рутини. И поред жеље за навођењем актуелних дешавања његова писма откривају слабо познавање узрока многих негативних појава. Највећи значај имају у откривању криминалних појава, углавном везаних за најзначајније свечаност у граду (посебно карневал), али и указују на претензије Енглеске према млетачком тржишту, у доба када ова држава више није важила за водећу трговачку силу.

\footnotetext{
Austria, and the Turks in the Seventeenth Century, Philadelphia 1991, 426-427. О узроцима рата вид.: Аmу А. Bernardy, L' Ultima Guerra turco-venetiana (MDCCXIV-MDCCXVIII), Florence 1902, 11-20.

${ }^{103}$ Monthly Mercury, vol. XXV... For the Month of December, 471.
} 


\title{
CIRCUMSTANCES IN VENICE BEFORE THE SECOND MOREAN WAR: EVIDENCE FROM ENGLISH SOURCES
}

\begin{abstract}
Summary
Writings of Christian Cole describe occurrences relevant for the social history of Venice in this period. He did not oversee the crimes committed by members of the governmental structures. Names of courtesans listed in his correspondence reveal that Cole was familiar with this phenomenon of Venetian everyday life, which managed to subsist for centuries. Relatively good knowledge about the situation in the Patriciate was supplemented by Cole's report on the introduction of state lottery in 1714, with Venice following the „Netherlands model“, trying to improve it. In this field, his reports represent the best source of non-Venetian provenance.

Senate sessions, during which decisions of relevance for the state were reached, have a significant place in his letters, as well as the persons who visited St. Mark's city in this period. Years 1713-1714 were marked by negotiations in Utrecht and Rastatt, which created a new political map of Europe, defining the borders that would remain for several decades (until 1746). Austria's penetration in Italy is one of the most important outcomes, and that could not leave Venice aside. Opinions on current events echoed in reports that he sent to England, based on his own point of view.

Christian Cole's Venice represents a city emerged in its own magnitude, with everyday life stuck in a rut. Although he wishes to write about relevant events, his letters reveal little knowledge of causes of many negative occurrences. Their greatest significance is for revealing the criminal deeds, mainly related to the most important celebrations in the city (especially the Carnival), but they also indicated English claims to the Venetian market in the period when this state was no longer a leading mercantile power.
\end{abstract}

Keywords: Venice, Christian Cole, crime, plague, Peace of Utrecht, lottery. 